\title{
Pensononowoor
}

2019 , vol. $81,40-46$

http://dx.doi.org/10.12657/denbio.081.005

\author{
Pawet Przybylski, Jan Kowalczyk, Ireneusz Odrzykoski, Jan Matras
}

\section{Identyfing alien genotypes and their consequences for genetic variation in clonal seed orchards of Pinus sylvestris L.}

Received: 11 April 2018; Accepted: 14 May 2019

\begin{abstract}
This study investigates the rates of grafting and planting errors that occur in seed orchards, and evaluates their effects on the genetic diversity and relatedness of genotypes.

The study used three clonal Scots pine seed orchards of differing ages and clonal composition located in the forest districts of Susz, Pniewy and Zdrojowa Góra, Poland. Maximum breeding ability within a seed orchard requires isolated from external sources of pollen, and have no alien genotypes inside the orchard. We used 13 isoenzyme markers to determine the genotypic identity of ramets and compared the number of genotypes of the actual current ramet population (W1) with genotypes comprising the originally intended plus trees (designated as W0) to estimate the genotypic assignment error rate per orchard. For both W0 and $\mathrm{W} 1$, we calculated the effective number of clones and the relative effective number of clones.

Ramet assignment errors were detected in all three seed orchards. Gnotypic errors ranged from $5.8 \%$ to $37.7 \%$ across orchards. A total of 46 alleles were found, with the mean number of alleles per locus ranging from 2.77 to 3.23. At individual loci, the level of observed heterozygosity was variable. Alien genotypes had negligible effects on seed orchard heterozygosity. The Fst values between seed orchards amounted to $0.6 \%$ between Susz and Pniewy and $1.1 \%$ between Susz and Zdrojowa Góra.

The effect on genetic variation of ramet assignment errors was small and influenced genetic diversity only in the case of the Susz seed orchard. However, our results suggest that negative effects of alien genotypes can occur on breeding value of seeds from analysed seeds orchards.
\end{abstract}

Keywords: genetic analysis, Pinus sylvestris, tree breeding, isoenzyme marker, grafting error

Addresses: P. Przybylski, J. Kowalczyk, J. Matras, Forest Research Institute, Sękocin Stary, 3 Braci Leśnej Street, 05-090 Raszyn, Poland, e-mail: p.przybylski@ibles.waw.pl

I. Odrzykoski, Adam Mickiewicz University, Department of Genetics, Institute for Experimental Biology,

61-614 Poznan, Poland

\section{Introduction}

Reforestation and afforestation in Poland increasingly rely on seeds produced in seed orchards (Przybylski, 2015). It is expected that seeds from seed orchards reflect the gene pool of the plus trees that were selected as breeding parents for the orchard. Ideally seed orchards should constitute an isolated and panmictic population, but this is almost impossible to achieve in practice (Gömöry et al., 2003). This primarily stems from asynchrony of ramet flowering, their variable fertility (Burczyk \& Chałupka, 1997; Gömöry et al., 2003), erroneous placement of clones within seed orchards, and pollen contamination (Slavov et 
al., 2005). It is assumed that pollen contamination (alien pollen) comes from trees outside of the seed orchard (Burczyk \& Chybicki, 2004), and from non-plus trees erroneously planted in the orchard (Gömöry et al., 2003). The latter type of errors in seed orchard establishment was described in Poland by Odrzykoski (2007), who classified them into two categories. Category I errors are caused by mistakes in the spatial architecture of the seed orchard, caused by misplacing ramets from among clones that are a part of the seed orchard design. The Category II errors arise from misidentification which causes individuals that are not part of the breeding population being accidentally introduced into the orchard (Odrzykoski, 2007). In clonal seed orchards, the Category II errors often result from the nursery management errors when a rootstock outgrowing a scion passes unnoticed.

These sources of error have different effects on the genetic diversity of a seed orchard and its progeny. Category I errors do not alter the gene pool of a seed orchard. However, they can increase the risk of self-pollination. By contrast, Category II errors modify the gene pool by introducing alien pollen, which reduces breeding efficiency (Kaya et al., 2006). Alien genotypes may also modify the basic genetic characteristics of seed orchards, influencing the heterozygosity coefficient and introducing unwanted alleles into the gene pool of seed orchard progeny.

In this paper, two hypotheses were tested:

- Category I and Category II errors modify the spatial architecture of clones in Pinus seed orchards and introduce alien trees that decrease the effective number of clones (sensu Kang et al., 2001), by changing the frequency of ramets per clone within seed orchards.

- Category I and II errors modify genetic attributes used to describe the genetic variation of seed orchards.

The main aim of the study was to determine the incidence of Category I and II errors in selected seed orchards in Poland. The secondary aim was to analyze the influence of such errors on the genetic variability among the seed orchard trees, and on the effective number of clones. The results of this study can contribute to improved seed orchard management.

\section{Methods}

\section{Plant material}

This study was performed in three clonal seed orchards, each located in a different forest district in Poland. The Susz District seed orchard (N53 $45^{\prime} 21^{\prime \prime}$, E19 $\left.{ }^{\circ} 2^{\prime} 16^{\prime \prime}\right)$ was established in 1977-1978; Zdrojowa Góra District (N537'20", E16 $\left.{ }^{\circ} 45^{\prime} 16^{\prime \prime}\right)$ seed orchard was established in 1983-1984, and Pniewy District seed orchard (N52 $\left.30^{\prime} 32^{\prime \prime}, \mathrm{E} 16^{\circ} 15^{\prime} 24^{\prime \prime}\right)$ was established in 1993. The analyzed seed orchards are of the first generation, and were planted with clones of phenotypically-selected plus trees from the wild stands. The progeny of those trees was not tested, thus their breeding values are unknown.

Winter dormant buds were collected to verify the genotypes of clones with those specified in the original planting design. Samples were collected from two blocks within each seed orchard from all trees that remained after the last systematic thinning (Table 3). The reference samples for the Susz and Zdrojowa Góra seed orchards came from the original plus trees. When it was not possible to collect reference material in this way, because plus trees were dead, a repeated set of 4 grafts from the tested seed orchard constituted the reference sample. For the Pniewy orchard, the reference samples were obtained from a clonal archive outside of the seed orchard.

\section{Genotype analysis}

Variation in eight enzymatic proteins extracted separately from winter buds of each tree was examined (Table 1). Protein extraction was conducted using a 150- $\mu$ l extraction buffer (Odrzykoski, 2002). After filtering through Miracloth filter paper, the resulting solutions were used to moisten pieces of Whatman 3ET filter paper, which were subsequently placed onto electrophoresis gel. Using two buffer systems (Odrzykoski, 2002, 2007), the electrophoresis was conducted in $13 \%$ starch gel (Starch-Art). Following electrophoresis, gels were cut into $1.5-\mathrm{mm}$ slices, which were individually used to visualize the phenotype of the analyzed proteins. Location of individual bands was determined using the methods of Conkle et al. (1982), with a modification comprising the use of an "agar overlay" procedure with $2 \%$ agar, excluding EstB and Got. Identification of the loci and interpretation of the obtained zymograms were carried out

Table 1. List of buffer systems (A, C), enzymes (with E.C. numbers), and enzyme loci used in this study

\begin{tabular}{clcc}
\hline $\begin{array}{c}\text { Sys- } \\
\text { tem }\end{array}$ & \multicolumn{1}{c}{ Enzyme } & No. E.C. & locus \\
\hline A & Esterase & 3.1 .1 .2 & EstB \\
& Glutamate-oxaloacetate transaminase & 2.6 .1 .1 & GotA \\
& & & GotB \\
& & GotC \\
& NADH-diaphorase & 1.8 .1 .4 & DiaC \\
& Glutamate dehydrogenase & 1.4 .1 .2 & Gdh \\
C $\quad$ 6-phosphogluconate dehydrogenase & 1.1 .1 .44 & PgdA \\
& Shikimate dehydrogenase & 1.1 .1 .25 & SdhA \\
& & & SdhB \\
& NAD-dependent malate dehydrogenase & 1.1 .1 .37 & MdhA \\
& & 1.1 .1 .1 & AdhA \\
& Alcohol dehydrogenase & & AdhB \\
\hline
\end{tabular}


using the approach described by Odrzykoski (2002). Only individuals, whose genotype at all examined loci had exactly the same genotype profiles on zymograms, were considered genetically homogeneous.

\section{Statistical analyses}

To determine the discrimination power of the clonal verification system, the cumulative probability of obtaining identical genotypes $\left(\mathrm{P}_{\mathrm{ID}}\right)$ for two different clones was calculated as:

$$
\mathrm{P}_{\mathrm{ID}}=2 *\left(\left(\sum \mathrm{p}_{\mathrm{i}}^{2}\right)^{2}-\sum \mathrm{p}_{\mathrm{i}}^{4}\right),
$$

where $p_{i}=$ the mean allele frequency (i) in the sample of grafts from the three tested seed orchards combined (Taberlet \& Luikart, 1999) (Table 2). Calculations were performed using GeneAlEx 6.5 software (Peakall $\&$ Smouse, 2006). The genotypes obtained from all ramets in the tested blocks of the seed orchards were used to estimate the Category I and II errors per orchard. To assess the influence of both categories of errors on the genetic composition of each seed orchard, the actual clone population and spatial arrangement of ramets as determined based on results of molecular analysis in each orchard (W1) was compared with the population of grafts originally planned for planting (W0), assuming no errors were made and all grafts were planted as described in seed orchard documentation. For both W0 and W1, the effective numbers of clones $(\mathrm{Nc})$ were calculated based on Kang and Lindgren (1999) and Kang et al. (2001), in which:

$$
\mathrm{Nc}=\frac{N g}{\left(\frac{C V \%}{100}\right)^{2}+1}
$$

Table 2. Comparison of individual and accumulated probability of obtaining identical genotypes $\left(\mathrm{P}_{\text {ID }}\right)$ for unrelated ramets in clones from three seed orchards combined. The loci were added in accordance to their order in the first column

\begin{tabular}{cccc}
\hline Locus & $\begin{array}{c}\text { Loci IZO } \\
13\end{array}$ & $\begin{array}{c}\mathrm{P}_{\text {ID }} \\
\text { (by locus) }\end{array}$ & $\begin{array}{c}\mathrm{P}_{\text {ID }} \\
\text { (locus combination) }\end{array}$ \\
\hline 1 & EstB & 0.41 & 0.4161 \\
2 & PgdB & 0.39 & 0.1637 \\
3 & SdhA & 0.52 & 0.0858 \\
4 & SdhB & 0.82 & 0.0708 \\
5 & MdhA & 0.82 & 0.0581 \\
6 & MdhC & 0.41 & 0.0238 \\
7 & Gdh & 0.39 & 0.0093 \\
8 & DiaC & 0.54 & 0.0051 \\
9 & GotA & 0.91 & 0.0047 \\
10 & GotB & 0.31 & 0.0014 \\
11 & GotC & 0.37 & 0.0005 \\
12 & AdhA & 0.41 & 0.0002 \\
13 & AdhB & 0.38 & 0.00008 \\
\hline
\end{tabular}

where: $\mathrm{Ng}=$ corrected census number of genotypes after molecular verification, and $\mathrm{CV} \%=$ coefficient of variation for the number of ramets (Table 4). The relative effective number of clones was calculated as $\mathrm{Nr}=\mathrm{Nc} / \mathrm{N}$ (Kang et al., 2001).

Using GeneAlEx 6.5 software, the variability of isoenzyme loci was analyzed by calculating the allele frequency and the following diversity measures:

1. mean allele number $\left(\mathrm{N}_{\mathrm{a}}\right)$ and effective allele number $\left(\mathrm{N}_{\mathrm{e}}\right)$ per locus,

2. mean observed heterozygosity $\left(\mathrm{H}_{\mathrm{o}}\right)$,

3. Wright's inbreeding coefficient $\left(F_{i s}\right)$ calculated using FSTAT 4.3 (Goudet, 2001),

4. Wright's differentiation statistics $\left(F_{s t}\right)$ (Wright 1969), and the significance of genetic differences based on the results of analysis of molecular variance (AMOVA) implemented in GeneAlex v 6.5 software, and 999 permutations to calculate the probability.

The Analysis of Molecular Variance follows the methods of e.g Peakall et al. (1996) and Michelakis and Excoffier (1996). AMOVA allows the hierarchical partitioning of genetic variation among populations and regions and the estimation of the widely used $F$ statistics or their analogues (GenAlex v 6.5 Manual). The statistical significance of the $F_{\text {st }}=0$ (no genetic variability) hypothesis was analyzed between seed orchards and between $\mathrm{W} 0, \mathrm{~W} 1$ variants inside seed orchards.

\section{Results}

The errors of both Category I and II were detected in all three investigated seed orchards (Table 3). The number of legitimate grafts planted in the wrong location (Category I errors) ranged from 8 in Zdrojowa Góra to 18 in Susz. The number of alien grafts planted in seed orchards (Category II errors) ranged from 1 in Zdrojowa Góra to 34 in Susz (Table 3). The highest numbers of both error types was observed seed orchard (a combined 37.7\% ramet assignment error rate). The greatest consistency with the original seed orchard design $(94.2 \%$, (Table 3$)$ ) was observed in Zdrojowa Góra.

The results confirm an increased corrected census number of genotypes $(\mathrm{Ng})$ (Table 4$)$ in all three seed orchards after molecular verification (W1) compared to the originally planned composition of these seed orchards (W0). The largest number of alien genotypes was found in the Susz seed orchard, i.e., $24.6 \%$ of all genotypes erroneously included at planting (Table 3 ). Errors did not entirely exclude any plus trees genotypes from the Zdrojowa Góra and Pniewy seeds orchards. In the Susz orchard the erroneously planted clones replaced 13 plus trees genotypes increasing the number of genotypes in the seed orchard by 20 
Table 3. Information about the three studied seed orchards. Percentage of ramets that were located correctly and incorrectly, and those that were of alien genotypes is given

\begin{tabular}{lccc}
\hline & Susz & $\begin{array}{c}\text { Zdrojowa } \\
\text { Góra }\end{array}$ & Pniewy \\
\hline $\begin{array}{l}\text { Year of establishment } \\
\text { Number of clones }\end{array}$ & 50 & 47 & 1978 \\
$\begin{array}{l}\text { Number of ramets in } \\
\text { seed orchards }\end{array}$ & 9838 & 2016 & 1733 \\
$\begin{array}{l}\text { Number of studied } \\
\text { ramets }\end{array}$ & 138 & 154 & 131 \\
$\begin{array}{l}\text { Number of correctly } \\
\text { located ramets }\end{array}$ & 86 & 145 & 105 \\
$\begin{array}{l}\text { Number of incorrectly } \\
\text { located ramets - }\end{array}$ & 18 & 8 & 14 \\
$\begin{array}{l}\text { Category I error } \\
\text { Number of ramets of } \\
\text { alien genotypes - } \\
\text { Category II error }\end{array}$ & 34 & 1 & 12 \\
\hline
\end{tabular}

Table 4. Corrected census number of genotypes after molecular verification $(\mathrm{Ng})$, coefficient of variation for the number of ramets (CV \%), mean number of ramets per genotype (Nsg), effective $(\mathrm{Nc})$ and relative effective $(\mathrm{Nr})$ number of clones in seed orchards

\begin{tabular}{lcccccc}
\hline & \multicolumn{2}{c}{ Susz } & \multicolumn{2}{c}{ Zdrojowa Góra } & \multicolumn{2}{c}{ Pniewy } \\
\hline $\mathrm{IZO}$ & $\mathrm{W} 0$ & $\mathrm{~W} 1$ & $\mathrm{~W} 0$ & $\mathrm{~W} 1$ & $\mathrm{~W} 0$ & $\mathrm{~W} 1$ \\
$\mathrm{Ng}$ & 50 & 57 & 47 & 48 & 53 & 65 \\
$\mathrm{CV}(\%)$ & 39 & 62 & 44 & 45 & 43 & 53 \\
$\mathrm{Nsg}$ & 2.76 & 2.42 & 3.27 & 3.21 & 2.47 & 2.01 \\
$\mathrm{Nc}$ & 43.28 & 41.13 & 39.39 & 39.92 & 44.81 & 50.92 \\
$\mathrm{Nr}$ & 0.87 & 0.72 & 0.84 & 0.83 & 0.84 & 0.78 \\
\hline
\end{tabular}

W0 - population of grafts originally planned for planting in seed orchards; W1 - corrected graft population.

Table 5. Genetic diversity of seed orchards averaged across all analyzed loci

\begin{tabular}{ccccccc}
\hline \multirow{2}{*}{ Mean } & \multicolumn{2}{c}{ Susz } & \multicolumn{2}{c}{ Zdrojowa Góra } & \multicolumn{2}{c}{ Pniewy } \\
\cline { 2 - 7 } & W0 & W1 & W0 & W1 & W0 & W1 \\
\hline $\mathrm{N}_{\mathrm{a}}$ & 2.92 & 2.92 & 3.23 & 3.23 & 2.77 & 2.85 \\
$\mathrm{~N}_{\mathrm{e}}$ & 1.58 & 1.60 & 1.57 & 1.57 & 1.58 & 1.59 \\
$\mathrm{H}_{\mathrm{o}}$ & 0.34 & 0.37 & 0.32 & 0.32 & 0.34 & 0.34 \\
$\mathrm{~F}_{\text {is }}$ & -0.03 & -0.05 & 0.02 & 0.02 & -0.03 & -0.02 \\
\hline
\end{tabular}

W0 - population of grafts originally planned for planting in seed orchards; W1 - corrected graft population $\mathrm{N}_{2}$ - average number of alleles; $\mathrm{N}_{\mathrm{e}}$ - average effective number of alleles; $\mathrm{H}_{\mathrm{o}}-$ observed heterozygosity; $F_{i s}-$ Wright's inbreeding coefficient. alien genotypes. Therefore the increased corrected census number in Susz reflects not only additional alien clones, but also some replacement of original clones. Thus, external genotypes reduced the average number of grafts per clone, particularly in the Pniewy and Susz seed orchard, but only marginally in the Zdrojowa Góra seed orchard. Our analyses confirmed the influence of alien grafts both on the effective number of clones and the relative effective number of clones in seed orchards Susz and Pniewy (Table 4). The relative effective number of clones in the W1 group was reduced in the Susz and Pniewy orchards.

In total, 46 alleles were found across the 13 loci tested. Mean number of alleles per locus ranged from 2.77 to 3.23. At individual loci, the level of observed heterozygosity was variable. The occurrence of alien genotypes in the W1 group influenced the observed heterozygosity $\left(\mathrm{H}_{\mathrm{o}}\right)$ only for the Susz orchard (Table $5)$. Across all seed orchards, $H_{o}$ ranged from 0.32 in Zdrojowa Góra to 0.37 in Susz (Table 5).

The inbreeding coefficient $\left(F_{i s}\right)$ did not vary significantly among individual loci. However, its mean value for the analyzed samples was close to zero (from -0.05 to 0.02 ). Slightly more heterozygotes were found in Susz and Pniewy relative to Zdrojowa Góra (Table 5). No differences in $F_{\text {is }}$ values were found between W1 and W0 groups for Pniewy and Zdrojowa Góra, although detected for the Susz seed orchard.

A comparison between W0 and W1 groups within each seed orchard indicates only a slight and not significant influence of alien grafts on the indices of genetic differentiation (Table 6). When comparing between seed orchards the $F_{s t}$ values in the W0 group ranged from 0.009 to 0.012 , and were statistically significant for each pair of compared seed orchards (Similar values were found when comparing W1 groups (Table 6). This indicates that assignment errors did not alter the genetic variation between the seed orchards compared to the planned design. Based on the $F_{s t}$, only $0.6 \%$ to $1.1 \%$ of gene variation resides among the seed orchards after identifying errors, which is not different from variation found based on the original design.

Table 6. Fixation index $\left(F_{\text {st }}\right)$ for seed orchards and the planned (W0) and actually planted (W1) genotypes in examined seed orchard. Comparisons between the W0 and W1 in each orchard are in bold. $F_{\text {st }}$ values below the diagonal. Probability of Ho: $F_{s t}=0$ (rand $>=$ data) based on 999 permutations is shown above diagonal. Differentiation not significant (NS), * significant $\mathrm{p}<0.05^{* *} \mathrm{p}<0.01$

\begin{tabular}{lccccccc}
\hline & & \multicolumn{2}{c}{ Susz } & \multicolumn{2}{c}{ Pniewy } & \multicolumn{2}{c}{ Zdrojowa Góra } \\
\cline { 3 - 8 } & & W0 & W1 & W0 & W1 & W0 & W1 \\
\hline Susz & W0 & & $\mathbf{0 , 3 6 3 ~ N S}$ & $0,001^{* *}$ & $0,001^{* *}$ & $0,001^{* *}$ & $0,001^{* *}$ \\
\multirow{3}{*}{ Pniewy } & W1 & $\mathbf{0 , 0 0 2}$ & & $0,002^{* *}$ & $0,011^{*}$ & $0,001^{* *}$ & $0,001^{* *}$ \\
& W0 & 0,009 & 0,006 & & $\mathbf{1 , 0 0 0} \mathbf{N S}$ & $0,001^{* *}$ & $0,001^{* *}$ \\
\multirow{2}{*}{ Zdrojowa } & Góra & 0,008 & 0,005 & $\mathbf{0 , 0 0 0}$ & & $0,001^{* *}$ & $0,001^{* *}$ \\
& W1 & 0,013 & 0,011 & 0,012 & 0,010 & & $\mathbf{1 , 0 0 0 ~ N S}$ \\
& W0 & 0,014 & 0,011 & 0,011 & 0,010 & $\mathbf{0 , 0 0 0}$ & \\
\hline
\end{tabular}


The AMOVA analysis did not indicate significant differences between the W0 and W1 groups within the seed orchards. On the other hand, significant differences $(\mathrm{p}=0.02)$ between the seed orchards (at W0) were found, with an overall level of genetic diversity of $2 \%$.

\section{Discussion}

Seed orchards are a primary component of forest tree breeding cycle, through which genetic gain is introduced into subsequent forests (David et. al., 2003; Chałupka, 2005; Kowalczyk \& Filipovics, 2007). In addition, grafts from seed orchards are used as a material for scientific studies (e.g., Prus-Głowacki et al., 2015). Thus, for practical and scientific reasons it is important that labelling of ramets is correct and the clone integrity is maintained in seed orchards.

In this study we used the isoenzyme analysis to identify individual genotypes in seed orchards. This method is an effective, cheap and relatively simple technique for the genetic identification of individual forest trees, but it requires manual work (USDA Forest Service, 2001). Isoenzyme analysis has been widely used to determine the genetic variation and genetic structure of natural populations and seed orchards (Paule et al., 1993). Using this method, Paule (1991), Burczyk et al. (2000), and Gömöry et al. (2003) documented the occurrence of ramets erroneously assigned to genotypes in seed orchards. Although the isoenzyme analysis is an older technique that has largely fallen out of use, it had sufficient sensitivity to verify the genetic composition of genotypes within seed orchards in this trial $\left(\mathrm{P}_{\text {ID }}\right.$ of $0.00008)$ (Table 2). Given the total number of Scots pine plus trees in Poland ( $\sim 3650$, unpublished data of the Forest Research Institute), indicates that our method had enough discriminatory power to uniquely identify all plus trees of Scots pine in Poland. Other verification methods such as haplotypes of 6 microsatellite sequences in chloroplast DNA had discriminatory power $\mathrm{P}_{\mathrm{ID}} 0.004$ (Dzialuk \& Burczyk, 2005). It should emphasized that the price of isoenzyme analysis is several times lower compared to DNA analysis, which makes this method particularly attractive.

In forestry practice it is often assumed that no assignment errors exist in seed orchards. However, as indicated by our results, and also based on other studies (Paule, 1991; Burczyk et al., 2000; Gömöry et al., 2003; Kaya \& Isik, 2010), identification errors are rather common in seed orchards. This stems from the complex procedures required for seed orchard establishment and maintenance. Alien genotypes may be introduced into seed orchards due to errors during collection and labelling of scions, or when grafts are accidentally removed instead of the rootstock at the nursery. In the seed orchards examined in this study the percentage of erroneously assigned grafts ranged from $5.8 \%$ to $37.7 \%$, of which alien genotypes (Category II error) were responsible for $0.6 \%$ to $24.6 \%$ of the errors (Table 3 ). In a previous study, the average occurrence of Category I (misplaced ramet) and Category II errors in Polish seed orchards was found to be about 13\% (Przybylski, 2015). However, the number of alien genotypes in seed orchards may reach nearly 40\% (Gömöry et al., 2003), thus the Category II errors may be a significant factor affecting genotype frequencies in seed orchard and expected value of progeny.

The influence of these errors on the effective clone number in seed orchards has been poorly studied. Effective clone number is a simplified theoretical measure of the proportion of individuals participating in mating, based on variation in the number of ramets per clone (Kang et al., 2001). The results obtained here suggest a significant influence of misidentification errors on the effective clone number. Based on the relative effective number of clones $(\mathrm{Nr})$, the number of clones participating in reproduction was substantially reduced in two out of three examined seed orchards, relative to the number of clones given in the seed orchard plan. The effective clone number was $17,7 \%$ lower than the planned number in the case of the Susz orchard. As in Trojankiewicz and Burczyk (2005), the present results indicate a lower than expected relative effective number of clones in Polish seed orchards. It should be emphasized that no assignment errors were taken into account by Trojankiewicz and Burczyk (2005), however, these errors, as demonstrated in the present study, have a significant and negative influence on the relative effective number of clones.

The error level in seed orchards should be considered also in the context of changes in genetic composition of seed orchard progeny. For panmixia, the frequency of ramets of particular clones in an orchard should be identical to equalize the probability of cross-pollination among clones. Also, the spatial distribution should maximize distance between ramets of the same clone within the orchard (Trojankiewicz \& Burczyk, 2005). When the above assumptions are not fulfilled, or when flowering among clones is asynchronous or with large differences among clones in flowering abundance, the increased frequency of cross-pollination with alien pollen from outside the seed orchard or related-matings within the orchard can occur (Burczyk, 1998). The results of this study indicate that alien pollen in seed orchards also can be of internal origin, arising from Category II errors. In the most extreme case of the Susz seed orchard we observed some replacements at planting of the 13 originally planned genotypes with the alien genotypes. This indicates possible planting errors in the 
oldest Scots pine seed orchards, which have an effect on genetic composition and likely on progeny of these orchards. However, the examination of the effects of the assignment error on the seed orchard progeny was not the objective of this study.

The estimation of breeding values for clones represented in seed orchards (and the mean genetic value among orchards) can be affected either positively or negatively by gamete contributions from non-orchard pollen parents. Those estimates could be lowered for the negative effects of contaminating pollen or "alien" pollen within the orchard, and raised for the beneficial effects of supplemental pollen from more frequent ramets of high-ranked clones (Stoehr \& Woods, 2004). It is of interest how the error level identified in this study would affect breeding value estimates. Unfortunately, clones included in this present study were not progeny-tested, thus we have no information regarding their breeding value.

The results obtained in the present study did not prove the influence of alien genotypes on the genetic pool of the seed orchards. The genetic diversity between the W0 and W1 groups, calculated on the basis of AMOVA, was not statistically significant. This result is probably due to the small number of clones forming the evaluated seeds orchards . A larger sample size may indicate a larger influence of alien genotypes on the genetic structure of seeds orchards. We would like to emphasize that when analyzing seed orchard progeny attention should be paid to variation among clones in seed germination capacity, which may affect the genetic diversity of seed lots by causing under- or overestimation of their effective population size (Funda et al., 2012; Funda et al., 2015; Gömöry et al., 2000). Therefore, in the future, research on seed orchards should be broadened to include those effects on seed orchard progeny.

In conclusion, Category I and II errors affected genetic architecture of seed orchards and effective clone numbers. Seed orchard management would benefit from the identification of an acceptable assignment error level for Polish seed orchards. Clone verification could then be carried out where warranted, assignment errors remedied by graft removal or replacement. Using the sampling procedure employed in this study, seed orchards could be screened to estimate assignment error levels, followed with more thorough verification carried out in seed orchards with high indicated rates of error.

\section{Acknowledgments}

This project was funded by the Ministry of Science and Higher Education within the statutory activity of the IBL (240233) and partially from the Ministry of Science and Higher Education project N30900432/0658 (I.O.).

\section{References}

Burczyk J (1998) Systemy kojarzenia drzew iglastych. Wydawnictwo Uczelniane WSP, Bydgoszcz.

Burczyk J \& Chałupka W (1997) Flowering and cone production variability and its effect on parental balance in Scots pine clonal seed orchard. Annales des Sciences Forestières 54: 129-144. doi:10.1051/forest:19970201.

Burczyk J, Dzialuk A \& Lewandowski A (2000) Zmienność genetyczna sosny zwyczajnej (Pinus sylvestris L.) na klonowej plantacji nasiennej $\mathrm{w}$ Gniewkowie. Sylwan 144: 65-74.

Burczyk J \& Chybicki I (2004) Cautions on direct estimation of gene flow in plant populations. Evolution 58: 956-963. doi:10.1111/j.0014-3820.2004. tb00430.

Chałupka W (2005) Przeciwdziałanie redukcji różnorodności genetycznej w programach hodowli selekcyjnej. Ochrona leśnych zasobów genowych i hodowla selekcyjna drzew leśnych w Polsce stan i perspektywy. Międzynarodowa Konferencja Naukowo-Techniczna. Malinówka. Wydawnictwo Świat, Warszawa, pp. 55-61.

Conkle MT, Hodgskiss PD, Nunnally LB \& Hunter SC (1982) Starch gel electrophoresis of conifer seeds: a laboratory manual. U.S.D.A. General Technical Report PSW-64.

David A, Pike C \& Stine R (2003) Comparison of selection methods for optimizing genetic gain and gene diversity in a red pine (Pinus resinosa Ait.) seedling seed orchard. Theoretical and Applied Genetics 107: 843-849. doi:10.1007/s00122-0031330-0.

Dzialuk A \& Burczyk J (2005) Examination of chloroplast and nuclear microsatellite DNA sequences for individual identification of coniferous trees. Problems of Forensic Sciences 64: 395-400.

Funda T, Lstiburek M, Klapste J \& El-Kassaby Y (2012) Optimization of genetic gain and diversity in seed orchard crops considering variation in seed germination. Scandinavian Journal of Forest Research 27: 787-793. doi:10.1080/02827581.20 12.686627 .

Funda T, Wennström U, Almqvist C, Torimaru T, Gull BA \& Wang G (2015) Low rates of pollen contamination in a Scots pine seed orchard in Sweden: the exception or the norm? Scandinavian Journal of Forest Research 30: 573-586. doi:10.1080/028 27581.2015.1036306.

Gömöry D, Bruchánik R \& Paule L (2000) Effective population number estimation of three Scots pine (Pinus sylvestris L.) seed orchards based on an integrated assessment of flowering, floral phenology, and seed orchard design. Forest Genetics 7: 65-75. 
Gömöry D, Bruchánik R \& Longauer R (2003) Fertility variation and flowering asynchrony in Pinus sylvestris: consequences for the genetic structure of progeny in seed orchards. Forest Ecology and Management 174: 117-126. doi:10.1016/S0378$1127(02) 00031-2$.

Goudet J (2001) FSTAT 2.9. 3.2, a program to estimate and test gene diversities and fixation indices. https://www2.unil.ch/popgen/softwares/ fstat.htm.

Kang KS, Harju AM, Lindgren D, Nikkanen T, Almqvist C \& Suh GU (2001) Variation in effective number of clones in seed orchards. New Forests 21: 17-33. doi:10.1023/A:1010785222169.

Kang KS \& Lindgren D (1999) Fertility variation among clones of Korean pine (Pinus koraiensis S. et Z.) and its implications on seed orchards management. Forest Genetics 6: 191-200.

Kaya N \& Isik K (2010) Genetic identification of clones and the genetic structure of seed crops in a Pinus brutia seed orchard. Turkish Journal of Agriculture and Forestry 34: 127-134.

Kaya N, Isik K \& Adams W (2006) Mating system and pollen contamination in a Pinus brutia seed orchard. New Forest 31: 409-416. doi:10.1007/ s11056-005-0876-x.

Kowalczyk J \& Filipovics M (2007) Wpływ różnych wariantów selekcji indeksowej na zmienność genetyczną i zysk genetyczny populacji hodowlanej sosny zwyczajnej. Leśne Prace Badawcze 4: 107123.

Michalakis Y \& Excoffier L (1996) A generic estimation of population subdivision using distances between alleles with special reference for microsatellite loci. Genetics 142: 1061-1064.

Odrzykoski I (2007) Weryfikacja zgodności genetycznej szczepów sosny zwyczajnej na terenie plantacji nasiennej 08-14-3-11-95A-m-00 (PN34 C1) w Nadleśnictwie Zdrojowa Góra (RDLP Piła). Niepublikowany raport dla Nadleśnictwa Zdrojowa Góra.

Odrzykoski IJ (2002) Badania nad zmiennością genetyczną kosodrzewiny (Pinus mugo) z wykorzystaniem markerów biochemicznych i molekularnych. Wydawnictwo Naukowe UAM, Poznań.

Paule L (1991) Clone identity and contamination in a Scots pine seed orchard: Proceedings of the Meeting of the Nordic Group for Tree Breeding (ed. by D Lindgren) Swedish University of Agricultural Sciences, Department of Forest Genetics and Plant Physiology Umea 10: 22-32.
Paule L, Lidngren D \& Yazdani R (1993) Allozyme frequencies, outcrossing rate and pollen contamination in Picea abies seed orchards. Scandinavian Journal of Forest Research 8: 8-17. doi:10.1080/02827589309382751.

Peakall R \& Smouse P (2006) GENALEX 6: genetic analysis in Excel. Population genetic software for teaching and research. Molecular Ecology Notes. 6: 288-295 doi:10.1111/j.1471-8286.2005.01155.

Peakall R \& Sydes M (1996) Defining priorities for achieving practical outcomes from the genetic studies of rare plants: Back from the Brink: refining the threatened species recovery process (ed. by S Stephens \& S Maxwell) Surrey Beatty and Sons, Sydney, pp. 119-129.

Prus-Głowacki W, Sukovata L, Wosik-Lewandowska A \& Nowak-Bzowy R (2015) Shikimate dehydrogenase (E.C. 1.1.1. $25 \mathrm{ShDH}$ ) alleles potential markers for flowering phenology in Pinus sylvestris. Dendrobiology 73: 153-162. doi:10.12657/ denbio.073.016.

Przybylski P (2015) Czy na plantacjach nasiennych zawężamy zmienność genetyczną? Próba odpowiedzi na podstawie analiz mikrosatelitarnego DNA szczepów rosnących na plantacji nasiennej sosny zwyczajnej z Nadleśnictwa Susz. Leśne Prace Badawcze 76: 240-249. doi:10.1515-frp-2015-0023.

Slavov GT, Howe GT \& Adams WT (2005) Pollen contamination and mating patterns in a Douglas-fir seed orchard as measured by simple sequence repeat markers. Canadian Journal of Forest Research 35: 1592-1603. doi:10.1139/x05-082.

Stoehr M, Webber J \& Woods W (2004) Protocol for rating seed orchard seedlots in British Columbia: quantifying genetic gain and diversity. Forestry 77: 297-303. doi:10.1093/forestry/77.4.297.

USDA Forest Service (2001) Clonal identification in Douglas-fir (Pseudotsuga menziesii). Annual Report 2000-2001 (FY01), USDA Forest Service-NFGEL, 2375 Fruitridge Road, Camino CA, USA. http://www.fs.fed.us/psw/programs/nfgel/ annual reports/fy01.pdf.

Taberlet P \& Luikart G (1999) Non-invasive genetic sampling and individual identification. Biological Journal of the Linnean Society 68: 41-55. doi:10.1111/j.1095-8312.1999.tb01157.x.

Trojankiewicz M \& Burczyk J (2005) Efektywna liczba klonów na plantacjach nasiennych sosny zwyczajnej (Pinus sylvestris L.). Sylwan 149: 50-58.

Wright S (1969) Evolution and the genetics of populations: The theory of gene frequencies. Vol. 2. University of Chicago Press, Chicago. 